University of Nebraska - Lincoln

DigitalCommons@University of Nebraska - Lincoln

Identifying inter- and intra-guild feeding activity of an arthropod predator assemblage

James R. Hagler

USDA-ARS, james.hagler@ars.usda.gov

Felisa Blackmer

USDA-ARS

Follow this and additional works at: https://digitalcommons.unl.edu/usdaarsfacpub

Hagler, James R. and Blackmer, Felisa, "Identifying inter- and intra-guild feeding activity of an arthropod predator assemblage" (2013). Publications from USDA-ARS / UNL Faculty. 1254.

https://digitalcommons.unl.edu/usdaarsfacpub/1254

This Article is brought to you for free and open access by the U.S. Department of Agriculture: Agricultural Research Service, Lincoln, Nebraska at DigitalCommons@University of Nebraska - Lincoln. It has been accepted for inclusion in Publications from USDA-ARS / UNL Faculty by an authorized administrator of DigitalCommons@University of Nebraska - Lincoln. 


\title{
Identifying inter- and intra-guild feeding activity of an arthropod predator assemblage*
}

\author{
J A M E S R. H A G LER ${ }^{\dagger}$ and FE L I S A B L A C K M E R USDA-ARS, Arid-Land Agricultural \\ Research Center, Maricopa, Arizona, U.S.A.
}

\begin{abstract}
Understanding predator-prey interactions of the arthropod community in any given ecosystem is essential in pinpointing the biological control services provided by natural enemies.

2. Hence, four prey-specific polymerase chain reaction (PCR) assays were developed to analyse the gut contents of the cotton predator community. The four targeted prey included a herbivore/pest, omnivore/pest, omnivore/beneficial, and carnivore/beneficial.

3. First, prey retention tests were conducted to determine how long a prey item of each target species could be detected in a predator after ingestion. The assays yielded highly variable inter-assay and intra-assay prey detection efficiencies.

4. Then, a multifaceted field study was conducted to quantify the population dynamics of the cotton predator assemblage and to assess the frequencies of predation that each predator species exhibited on the targeted prey. In total, 1794 predators, representing 17 arthropod families, were collected over two seasons using both sweep net and whole plant sampling procedures.

5. The predator gut assays showed that there was substantial inter-guild predation occurring on the herbivore/pest, Bemisia tabaci (Gennadius); moderate intra-guild predation on the omnivore/pest, Lygus spp. (Lygus lineolaris (Palisot de Beauvois), L. hesperus Knight, and L. elisus Van Duzee) and the omnivore/beneficial, Geocoris spp. (Geocoris punctipes (Say), and G. pallens Stål); and very little intra-guild predation on the carnivore/beneficial, Collops vittatus (Say).

6. The gut assays also revealed that DNA of the targeted pests, B. tabaci and Lygus spp., were found more frequently in insect predators than spiders; whereas there were no significant differences in predation between the predatory insects and spiders for the beneficial insects, Geocoris spp. and C. vittatus.

7. Finally, there was a significantly higher frequency of predation events recorded for B. tabaci, Lygus spp., and Geocoris spp. in the sweep net samples. This indicates that the method of collection might influence the interpretation of the gut assay results.
\end{abstract}

Key words. arthropod sampling, biological control, food chain, predation, Predator gut analysis, trophic interactions

Correspondence: James Hagler, USDA-ARS, $21881 \mathrm{~N}$ Cardon Lane, Maricopa, AZ 85138, U.S.A. E-mail: james.hagler@ ars.usda.gov

*This article reports the results of research only. Mention of a proprietary product does not constitute an endorsement or a recommendation by the USDA for its use.

${ }^{\dagger}$ To whom a reprint request should be sent.

\section{Introduction}

It is well documented that many generalist arthropod carnivores and omnivores will readily prey on strict herbivore and omnivore cotton pests (Hagler \& Naranjo, 1994a,b; Hagler 2006, 2011), but very little is known about the feeding propensity of these predators on other beneficials. If any given predator species has a tendency to engage in intra-guild 
predation it could be antagonistic to the biological control of key pests (Rosenheim et al., 1993). As such, it is critical that we identify the biological control services provided by the various members of the arthropod predator community. However, identifying arthropod predator activity in nature is difficult. Direct visual observations of predation in situ are rare and lack consistency because predators and prey are small, elusive, and in many instances nocturnal. Also, obtaining direct observations of feeding activity is tedious and disruptive to the predator foraging process. As such, insect ecologists often resort to using indirect methods to study predation (Luck et al ., 1988). Postmortem predator gut content analysis is one of the most popular indirect methods for assessing predation. The two most common types of gut content assays are preyspecific enzyme-linked immunosorbent assays (ELISA) and polymerase chain reaction (PCR) assays. Historically, the vast majority of studies using these assays have focused solely on the examination of predation on a single economically important pest (Sheppard \& Harwood, 2005). However, the prey-specific PCR gut assay approach has recently been touted as the method of choice for studying food web interactions (King et al., 2008; Gagnon et al., a,b). The major advantages of this approach, when compared with the prey-specific ELISA approach, are that PCR assays are easier, faster, and less expensive to develop (Greenstone \& Shufran, 2003; Gariepy et al., 2007; Monzó et al., 2010). Numerous proof of concept studies showing that insect-specific PCR assays can be used as diagnostic tools to assess food web interactions have been published for over a decade (Agustí et al., 1999; Chen et al., 2000; de León et al., 2006); however, relatively few studies have focused on the application of the assays for mass screening of field-collected predators (e.g. most field studies published to date have small sample sizes). As King et al. (2008) succinctly stated, 'the task ahead is to start applying PCR molecular analysis techniques to study complex trophic interactions in the field.'

The main goal of this study was to identify the propensity that arthropod predators engage in intra- (e.g. high order predators feeding on lower order predators) and inter-guild predation (e.g. predators feeding on herbivores) on selected members of the cotton arthropod community. Pinpointing which predators are most likely to engage in inter-guild predation will be of significant value towards developing a conservation biological control programme on cotton pests. To accomplish this, we developed a suite of PCR assays to various prey items that occupy different trophic levels in the cotton ecosystem and then applied them to simultaneously (e.g. probe an individual predator's stomach contents for multiple prey items) examine the gut contents of the cotton predator assemblage.

\section{Materials and methods}

\section{Study organisms}

The suite of prey-specific PCR assays included: (i) sweet potato whitefly, Bemisia tabaci (Hemiptera: Aleyrodidae); (ii) Lygus spp. (Hemiptera: Miridae); (iii) Geocoris spp. (Hemiptera: Lygaeidae); and (iv) Collops vittatus (Coleoptera:
Melyridae). Lygus spp. and B. tabaci are currently the two most economically important pests of cotton and many other crops in the southwestern United States (Naranjo \& Ellsworth, 2009). Bemisia tabaci is a polyphagous herbivore that damages cotton by direct feeding which reduces lint production and quality. Members of the Lygus spp. complex in Arizona cotton include L. hesperus, L. lineolaris, and L. elisus. They are polyphagous omnivores that damage cotton by direct feeding on young cotton bolls which results in shedding of the fruit. The Geocoris spp. complex in Arizona cotton includes G. punctipes and G. pallens. They are abundant polyphagous omnivores that are harmless to cotton plants (Naranjo \& Gibson, 1996) and are widely regarded as a key predator in cotton. They are known to feed on a wide variety of prey including B. tabaci and Lygus spp. (Hagler \& Naranjo, 1994a; Hagler, 2011). The striped collops beetle, C. vittatus, is a carnivore that is commonly found in Arizona cotton fields. It has been documented as a voracious predator of the various lifestages of B. tabaci and immature L. hesperus (Hagler \& Naranjo, 1994b; Hagler, 2011).

\section{Prey-specific PCR assays}

DNA extraction. Arthropod specimens were weighed, placed individually in sterile 2.0-ml microtubes, and homogenised with a TissueLyser (Qiagen Inc., Valencia, Calfornia) for $1 \mathrm{~min}$ at $30 \mathrm{~Hz}$ in $180 \mu \mathrm{l}$ of phosphate-buffered saline (PBS, pH 7.2) using sterile 5-mm-stainless steel beads. A maximum of $50 \mathrm{mg}$ of tissue was individually processed. If a specimen weighed over $50 \mathrm{mg}$, it was homogenised in $360 \mu \mathrm{l}$ of PBS. The homogenates were then centrifuged at $4293 \mathrm{~g}$ (at $4{ }^{\circ} \mathrm{C}$ ) for 4 min. The DNA was then extracted from the samples using the DNeasy Blood and Tissue Kit (Qiagen Inc.). Samples that were homogenized in $360 \mu 1$ of PBS were split between two DNeasy mini spin columns. Total DNA was eluted twice in $30 \mu 1$ of AE buffer provided by the manufacturer. The DNA extracts were stored at $-20{ }^{\circ} \mathrm{C}$.

DNA quantification and normalisation. DNA extracts were quantified and normalised prior to PCR amplification to control for PCR amplification variation and quenching. A 1.5- $\mu \mathrm{l}$ aliquot from each DNA sample was taken for quantification with Thermo Scientific's Nanodrop 1000 (West Palm Beach, Florida). Each quantified sample was then normalised to a concentration of $40 \mathrm{ng} \mu \mathrm{l}^{-1}$, using sterile TE Buffer $(10 \mathrm{mM}$ Tris-HCl, 0.1 mM EDTA, $\mathrm{pH} 8.0$ ).

PCR amplification. The DNA extracted from each predator was analysed by a B. tabaci, Geocoris spp., Lygus spp., and C. vittatus-specific PCR assay that was designed to amplify the cytochrome oxidase subunit I (COI) gene for each species. COI sequences for each target species were obtained from the National Center for Biotechnology Information (NCBI) website and primers were designed using Primer3 software (see Table 1 for NCBI ascension numbers). The $B$. tabaci PCR amplifications were performed in $12.5-\mu 1$ reaction volume 
Table 1. Primer sequences and polymerase chain reaction (PCR) conditions for each prey-specific assay using the HotStarTaq master mix.

\begin{tabular}{|c|c|c|c|c|c|c|}
\hline \multirow[b]{2}{*}{$\begin{array}{l}\text { Targeted } \\
\text { prey }\end{array}$} & \multirow[b]{2}{*}{$\begin{array}{l}\text { GenBank accession } \\
\text { number }\end{array}$} & \multirow[b]{2}{*}{ Primer sequence } & \multicolumn{3}{|c|}{ PCR conditions } & \multirow[b]{2}{*}{$\begin{array}{l}\text { Product } \\
\text { size }(b p)\end{array}$} \\
\hline & & & Cycles & $\begin{array}{l}\text { Temperature } \\
\left({ }^{\circ} \mathrm{C}\right)\end{array}$ & $\begin{array}{l}\text { Time } \\
(\mathrm{s})\end{array}$ & \\
\hline Geocoris spp. & AY252919 & $\begin{array}{l}\text { 5'-GATACACGAGCTTACTTTAC } \\
5^{\prime} \text {-TCCTAGGGCTCATAATATTC }\end{array}$ & 40 & $\begin{array}{l}94 \\
56 \\
72\end{array}$ & $\begin{array}{l}30 \\
30 \\
30\end{array}$ & 131 \\
\hline Lygus spp. & $\begin{array}{l}\text { AY253038.1 } \\
\text { AY252909.1 }\end{array}$ & $\begin{array}{l}\text { 5'-AGGATTTGGACTAATCTCAC } \\
5^{\prime} \text {-ATTACTCCAGTAAGACCTCCT }\end{array}$ & 40 & $\begin{array}{l}94 \\
62 \\
72\end{array}$ & $\begin{array}{l}30 \\
30 \\
30\end{array}$ & 323 \\
\hline Collops vittatus & AY165674 & $\begin{array}{l}\text { 5'-GTTTACCCACCTTTATCTGG } \\
5^{\prime} \text {-CTAAAGTTATTCCTTGAGGTCG }\end{array}$ & 45 & $\begin{array}{l}94 \\
54 \\
72\end{array}$ & $\begin{array}{l}30 \\
30 \\
30\end{array}$ & 153 \\
\hline Bemisia tabaci & $\begin{array}{l}\text { AY057123 } \\
\text { AF164675.1 }\end{array}$ & $\begin{array}{l}\text { 5'-ACACTTATTTTGTTGTTGCAC } \\
5^{\prime} \text {-TAAAATTGAGACACCAATC }\end{array}$ & See text & or the $B . t a b a$ & PCR protocol & 139 \\
\hline
\end{tabular}

containing: $1 \mu \mathrm{l}$ of $40 \mathrm{ng} \mu \mathrm{l}^{-1}$ DNA extract, $0.5 \mu \mathrm{l}$ of $2.5 \mathrm{mM}$ deoxynucleotide triphosphates (New England BioLabs Inc., Ipswich, Massachusetts), $2.0 \mu \mathrm{l}$ of primers $(10 \mu \mathrm{M}), 0.1 \mu \mathrm{l}$ of HotStarTaq DNA Polymerase (QIAGEN Inc.), $1.25 \mu \mathrm{l}$ of Qiagen $10 \times$ PCR buffer, $1.25 \mu \mathrm{l}$ of $25 \mathrm{mM} \mathrm{MgCl}_{2}$ and $6.4 \mu \mathrm{l}$ of RNase-free water. Samples were amplified in a gradient thermal cycler (Eppendorf Mastercycler ${ }^{\circledR}$ gradient; Eppendorf, Westbury, New York) beginning with an initial denaturing step of $95^{\circ} \mathrm{C}$ for $15 \mathrm{~min}$ followed by 10 cycles of touchdown PCR at $94{ }^{\circ} \mathrm{C}$ for $30 \mathrm{~s}, 67^{\circ} \mathrm{C}$ for $30 \mathrm{~s}$, and $72^{\circ} \mathrm{C}$ for $30 \mathrm{~s}$, $-1{ }^{\circ} \mathrm{C} /$ cycle. Touchdown PCR was followed by 27 cycles at $94{ }^{\circ} \mathrm{C}$ for $30 \mathrm{~s}, 57^{\circ} \mathrm{C}$ for $30 \mathrm{~s}$, and $72^{\circ} \mathrm{C}$ for $30 \mathrm{~s}$ and a single cycle of $94^{\circ} \mathrm{C}$ for $15 \mathrm{~s}, 57^{\circ} \mathrm{C}$ for $15 \mathrm{~s}$, and $72^{\circ} \mathrm{C}$ for $15 \mathrm{~s}$. The PCR was finished with a 10-min extension at $72{ }^{\circ} \mathrm{C}$. The Geocoris spp., Lygus spp., and C. vittatus-specific assays were performed in $10-\mu$ l reaction volume containing: $3 \mu \mathrm{l}$ of $40 \mathrm{ng} \mu \mathrm{l}^{-1}$ DNA extract, $5 \mu \mathrm{l}$ of HotStarTaq Master Mix (Qiagen Inc.), and $2 \mu \mathrm{l}$ of $2.5 \mu \mathrm{M}$ species-specific primer mix (see Table 1 for primer sequences). Samples were amplified in the gradient thermal cycler according to the species-specific conditions given in Table 1.

For each prey-specific PCR assay, one positive control prey and one negative control (sterile TE) were included in the amplification. PCR products were separated by electrophoresis on $2 \%$ agarose gels $(130 \mathrm{~V}, 50 \mathrm{~min})$. Each gel was stained with ethidium bromide and the bands on the gel were visualised with the aid of a Bio-Rad Gel Doc ${ }^{\mathrm{TM}} 2000$ gel documentation system using Quantity One Software ${ }^{\mathrm{TM}}$ (Bio-Rad Laboratories, Hercules, California).

\section{PCR screening tests}

Key arthropod species indigenous to the Arizona agroecosystem were screened for reactivity to each of the four PCR gut assays described above (see those listed in Tables 2 and 3). All the arthropods screened for cross reactivity to the various assays were collected from alfalfa and cotton fields located at the University of Arizona's Maricopa Agricultural Center, Maricopa, Arizona, U.S.A. with the exception of Zelus renardii
(Kolenati) and Sinea confusa (Caudell) (Hemiptera: Reduviidae) which were colony reared on L. hesperus. All predaceous arthropods and potential herbaceous prey were isolated and placed into individual Petri dishes containing a wetted sponge for water for $48 \mathrm{~h}$ prior to DNA extraction. Then, each individual was assayed by the prey-specific PCR assays described above and in Table 1. An arthropod was scored positive when a PCR product amplified was the correct base pair (bp) size of the prey-specific PCR. Given the lack of cross-reactivity, these primers were deemed suitable for the analyses of predation in the cotton agroecosystem.

\section{Prey retention tests}

Predators. Prey-specific PCR assays were conducted on selected predators to determine how long a single prey item could be detected in their guts after feeding. Owing to the impracticality of conducting a feeding test for every possible predator-prey interaction that might occur in the agroecosystem, we only conducted feeding tests on some of the more common species. The spiders used in the feeding bioassays [Misumenops celer Hentz and Phidippus audax (Hentz)] were collected from a nearby cotton field, $Z$. renardii and $S$. confusa were reared in the laboratory on L. hesperus nymphs, and Hippodamia convergens GuérinMéneville and Chrysoperla carnea (Stephens) were purchased from various producers of biological control agents. Each individual predator was provided water, but deprived from foodstuffs for at least $48 \mathrm{~h}$ prior to the feeding trials to empty their gut and to expedite the predation events. Predators serving as negative controls were assayed after starving. All predator samples were assayed by the prey-specific PCR assays described above. A predator was scored positive when a PCR product amplified that was the correct bp size of the preyspecific PCR.

Prey. The prey offered to the individual predators included an adult $B$. tabaci, an adult $C$. vittatus, a second instar $G$. punctipes, or a third instar L. hesperus. Collops vittatus and 
Table 2. A listing of the members of the cotton predator assemblage collected and assayed for the presence of Bemisia tabaci, Lygus spp, Geocoris spp., and Collops vittatus prey remains.

\begin{tabular}{|c|c|c|c|c|c|c|}
\hline Order & Family & Predominate taxon & Common name & $\begin{array}{l}\text { Lifestage(s) } \\
\text { examined* }\end{array}$ & Classification $^{\dagger}$ & $\begin{array}{l}\text { Predominate } \\
\text { habitat }^{\sharp}\end{array}$ \\
\hline \multicolumn{7}{|l|}{ Insects } \\
\hline \multirow[t]{5}{*}{ Hemiptera } & Lygaeidae & Geocoris spp. ${ }^{\S}$ & Big-eyed bug & $\mathrm{J}, \mathrm{A}$ & Omnivorous predator & Foliar \\
\hline & Miridae & Lygus spp. ${ }^{\mathbb{I I}}$ & Lygus bug & $\mathrm{J}, \mathrm{A}$ & Omnivorous pest & Foliar \\
\hline & Nabidae & Nabis alternatus & Damsel bug & $\mathrm{J}, \mathrm{A}$ & Omnivorous predator & Foliar \\
\hline & Reduviidae & Sinea confusa & Assassin bug & $\mathrm{J}, \mathrm{A}$ & Carnivorous & Foliar \\
\hline & & Zelus renardii & Assassin bug & $\mathrm{J}, \mathrm{A}$ & Carnivorous & Foliar \\
\hline \multirow{2}{*}{ Coleoptera } & Melyridae & Collops vittatus & Flower beetle & A & Carnivorous & Foliar \\
\hline & Coccinellidae & Hippodamia convergens & Lady beetle & $\mathrm{A}$ & Carnivorous & Foliar \\
\hline Neuroptera & Chrysopidae & Chrysoperla carnea & Green lacewing & $\mathrm{J}$ & Carnivorous & Foliar \\
\hline Dermaptera & Forficulidae & Forficula auricularia & Common earwig & $\mathrm{J}, \mathrm{A}$ & Omnivorous & Ground \\
\hline \multicolumn{7}{|l|}{ Spiders } \\
\hline \multirow[t]{9}{*}{ Araneae } & Araneidae & Various & Orb weavers & $\mathrm{J}, \mathrm{A}$ & Carnivorous-web & Foliar \\
\hline & Clubionidae & Clubiona spp. & Sac spider & $\mathrm{J}, \mathrm{A}$ & Carnivorous-hunting & Foliar \\
\hline & Corinnidae & Trachelas spp. & Dark sac spider & $\mathrm{J}, \mathrm{A}$ & Carnivorous-hunting & Ground \& Foliar \\
\hline & Dictynidae & Dictyna reticulata & Mesh webweaver & $\mathrm{J}, \mathrm{A}$ & Carnivorous-web & Foliar \\
\hline & Gnaphosidae & Various & Ground spiders & $\mathrm{J}, \mathrm{A}$ & Carnivorous-hunting & Ground \\
\hline & Lycosidae & Hogna spp. & Wolf spider & $\mathrm{J}, \mathrm{A}$ & Carnivorous-hunting & Ground \& Foliar \\
\hline & Miturgidae & Cheiracanthium inclusum & Long-legged sac spider & $\mathrm{J}, \mathrm{A}$ & Carnivorous-hunting & Foliar \\
\hline & Salticidae & Various & Jumping spiders & $\mathrm{J}, \mathrm{A}$ & Carnivorous-hunting & Foliar \\
\hline & Thomisidae & Misumenops celer & Crab spider & $\mathrm{J}, \mathrm{A}$ & Carnivorous-hunting & Foliar \\
\hline
\end{tabular}

$* \mathrm{~J}=$ juvenile; $\mathrm{A}=$ adult.

$\dagger$ The primary feeding niche of each species.

$\ddagger$ The primary habitat of each species.

$\S$ The Geocoris spp. complex consisted of G. pallens and G. punctipes.

ITThe Lygus spp. complex consisted of L. lineolaris, L. hesperus, and L. elisus.

G. punctipes were obtained from a laboratory colony reared on Pectinophora gossypiella (Saunders) eggs, B. tabaci were obtained from a laboratory colony reared on cotton, and $L$. hesperus were obtained from a laboratory colony reared on an artificial diet (Debolt, 1982).

Prey retention tests. Individual predators were placed into 4.0-cm-diameter Petri dishes containing one of the prey items. After the predator was observed consuming the prey, it was isolated from food (except for water) for various amounts of time after feeding. All feeding trials were conducted at $25^{\circ} \mathrm{C}$ under constant light. For the $\geq 24$-h prey retention treatments, the predators were maintained under a LD 16:8 h photoperiod at $25^{\circ} \mathrm{C}$. After each post-feeding interval, predators were frozen at $-80^{\circ} \mathrm{C}$ until they could be processed and assayed by the appropriate prey-specific PCR assay described above.

\section{Field study}

Study site

The study was conducted in a 1.5-ha cotton field (Gossypium hirsutum L.) located at the University of Arizona Maricopa Agricultural Center, Maricopa, Arizona, U.S.A. The field was planted with the cotton cultivar, 'DP5415 RR', and grown using standard agronomic practices except that no insecticides were applied to the field.
The arthropods were collected on 8 August 2007 and 4 September 2008 using the whole plant sampling procedure described below. A complete listing of the field-collected predators and their feeding habits are given in Table 2. The whole plant sampling procedure provided an estimate of the arthropod densities on a per plant basis, but it is known that this procedure does not yield many predators for gut content analyses (James R. Hagler, pers. obs.). Hence, sweep net samples were also taken on 6 August 2007 and 2 September 2008 to augment the number of predators collected for the study.

Whole plant sampling procedure. Twenty-five canvas sleeve cages were put in each quadrant $(n=100$ per year) of the cotton field 2 days before sampling. The canvas sleeve cages were $100 \mathrm{~cm}$ long and $75 \mathrm{~cm}$ wide. Each cage was placed at the base of a cotton plant. The bottom of the cage was tied around the base of the plant with a drawstring and the top of the cage was left open at the base of the plant. This facilitated the redistribution of the arthropods on the plants. Then on each sampling date given above, the top of each sleeve cage was rapidly pulled up and over the entire plant [note that the plants were $\approx 0.8 \mathrm{~m}$ tall with a leaf surface area of $2850.9 \pm 876$ and $2722.5 \pm 942 \mathrm{~cm}^{2}$ in 2007 and 2008, respectively, as measured with a Li-3100 Area Meter (LiCor Inc., Lincoln, Nebraska)]. The base of each cotton plant was cut just below the bottom drawstring and the plants were frozen at $-20^{\circ} \mathrm{C}$ within $30 \mathrm{~min}$ 
after collection. Each whole plant sample was processed by removing it from the freezer and carefully searching the entire plant for predatory arthropods. Each predator was counted, its DNA was extracted, and then its stomach contents were analysed for the presence of B. tabaci, Lygus spp., Geocoris spp., and $C$. vittatus by the prey-specific PCR assays described above.

Sweep net sampling procedure. Twenty-five sweep net samples consisting of 10 sweeps each were taken down randomly selected rows in each quadrant of the cotton field $(n=100$ per year). Each sample was immediately placed in a plastic Ziploc ${ }^{\circledR}$ baggie, sealed, and placed in an ice chest. All sweep net samples were returned to the lab and frozen at $-20{ }^{\circ} \mathrm{C}$ within 30 min after collection. Each predatory arthropod was counted and assayed by each PCR assay described above.

Whitefly sampling procedure. The whole plant and sweep net sampling procedures are not well suited for estimating whitefly populations. Therefore, the whitefly population (all life stages) was estimated by taking a single leaf sample from 100 ( 25 per quadrant) randomly selected cotton plants each year. The in situ leaf turn method described by Naranjo and Flint (1995) was used to estimate the number of adult whiteflies on each leaf. Each turned leaf was then removed from the plant, and taken to the laboratory, where the number of whitefly eggs and nymphs on a 2.2-cm -diameter leaf disk was counted (Naranjo \& Flint, 1994).

Data analysis for arthropod populations. The arthropods collected from the whole plant and sweep net samples were pooled by taxa for the analyses for each collection method and year of the study. Descriptive statistics were calculated to determine the average $( \pm$ SEM) number of each predator taxa per plant and the average number collected per 10 sweeps with a net.

Data analysis for predator gut content assays. The four prey (DNA)-specific gut content PCRs described above were performed on every predator collected in the whole plant and sweep net samples. The proportion of individuals from each predatory taxa containing the targeted prey types was determined. As the number of predators (insects and spiders) collected in the whole plant samples was relatively low compared with the numbers collected in the sweep net samples, the data were pooled for each year of the study to simplify the data presentation. Descriptive charts were created to depict the overall frequency of predation events on each targeted prey species.

Differences in the apparent feeding activity on each prey type exhibited by: (i) the insect predator and spider complex, (ii) year of the study, and (iii) sampling method were determined by the $z$-test statistic with Yates correction for continuity using SigmaPlot 11.0 (Glantz, 1997; SigmaStat Ver. 2.02).

\section{Results}

\section{PCR screening tests}

Several key arthropod species were analysed for reactivity to each of the four prey-specific PCR gut assays prior to the initiation of the laboratory and field studies (data not shown). The Collops-specific assay was monospecific to C. vittatus. That is, it did not react to any of the other arthropod taxa from the cotton agroecosystem, including Collops quadrimaculatus (Fabricius) (which only comprised 3.2\% of the Collops spp. complex). The Bemisia-specific assay also proved to be monospecific when tested against other members of this cotton assemblage. Whether this assay reacts to other whitefly species is unknown and inconsequential because there were not any other whitefly species present in the cotton during the study. The Geocoris-specific PCR was genus specific as it only reacted to the Geocoris species found in cotton; G. punctipes and G. pallens (which comprised $70.7 \%$ and $29.3 \%$ of the Geocoris species complex, respectively). Similarly, the Lygusspecific PCR only reacted to three native Lygus species; L. elisus, L. hesperus, and L. lineolaris (which comprised $51.8 \%, 35.8 \%$, and $12.4 \%$ of the Lygus species complex, respectively).

\section{Laboratory prey retention tests}

The results yielded from the predator feeding tests for seven of the common predator taxa are given in Fig. 1. It should be noted that a feeding trail was not conducted on every predator-prey combination because some of the predators refused to feed on certain types of prey (e.g. very few of the predators examined would feed on adult $C$. vittatus). Each predator-prey combination was tested at three or four post feeding time intervals. Predators were examined for target prey DNA immediately after ingesting a single prey item, at 24 or $48 \mathrm{~h}$ after ingestion, and then at one or two post feeding intervals between the two extremes. For the most part, the prey-specific PCRs were effective at detecting a single prey item in a predator's stomach immediately after feeding. However, a single whitefly was detectable in $0 \%$ and only $20 \%$ of the spiders and G. punctipes, respectively. The frequencies of prey detection by the various assays beyond the 0 -h postfeeding interval were erratic. For example, the frequency of prey detection for $C$. vittatus, L. hesperus, and G. punctipes DNA in $Z$. renardii $24 \mathrm{~h}$ after feeding was $40 \%, 80 \%$, and $100 \%$, whereas the detection for the same prey items for another assassin bug, S. confusa, was $100 \%, 0 \%$, and $60 \%$, respectively.

The laboratory feeding tests also provided some insight on prey selection by the various predators. For instance, most of the predators readily preyed on an adult whitefly (Fig. 1a), and to a lesser extent, on an immature L. hesperus (Fig. 1b). However, Z. renardii and $S$. confusa would not feed on a whitefly; therefore prey decay data could not be obtained (Fig. 1a). Moreover, many of the predators were disinclined to feed on adult C. vittatus or G. punctipes in the feeding arenas (Fig. 1c,d). 


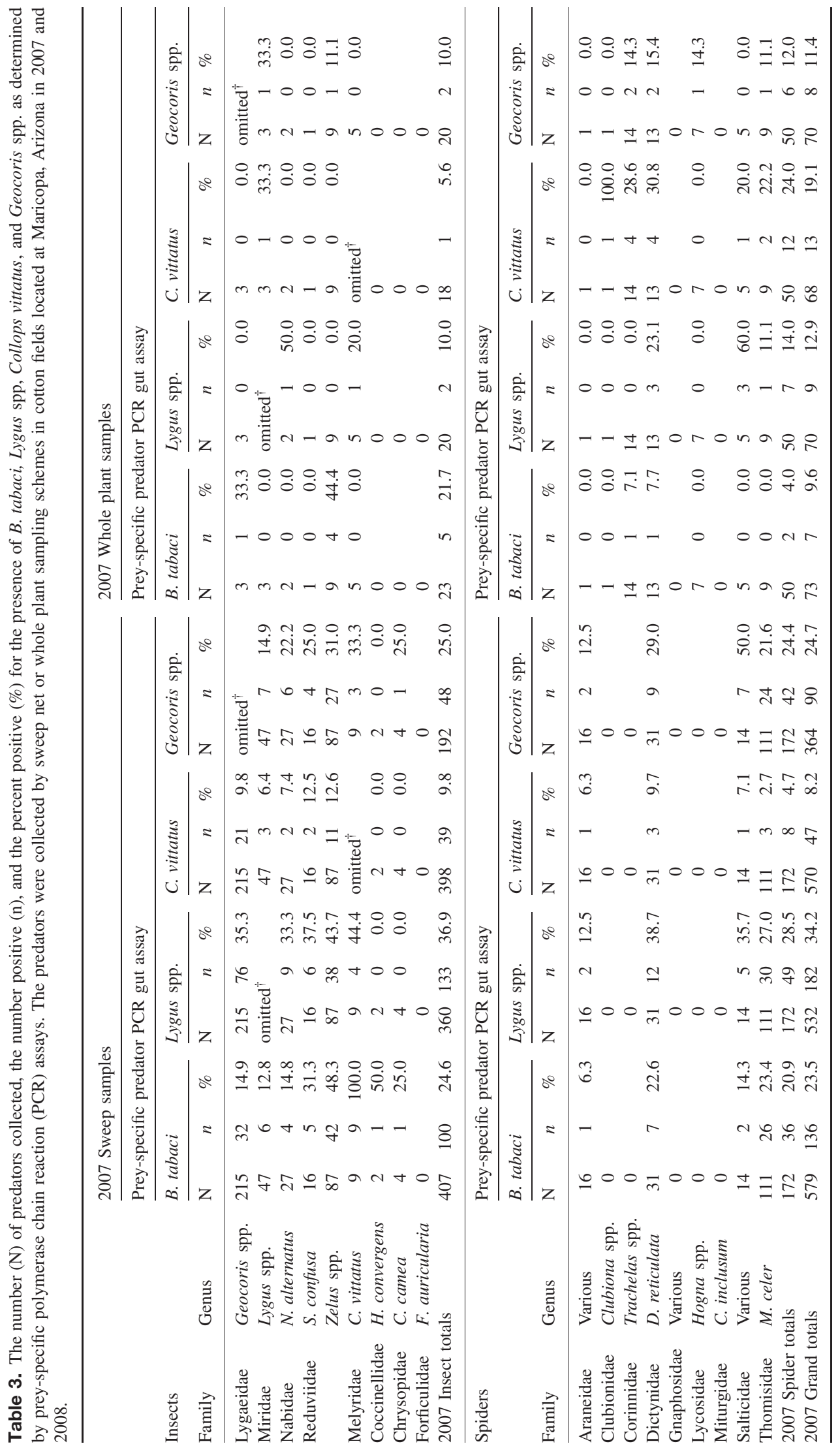




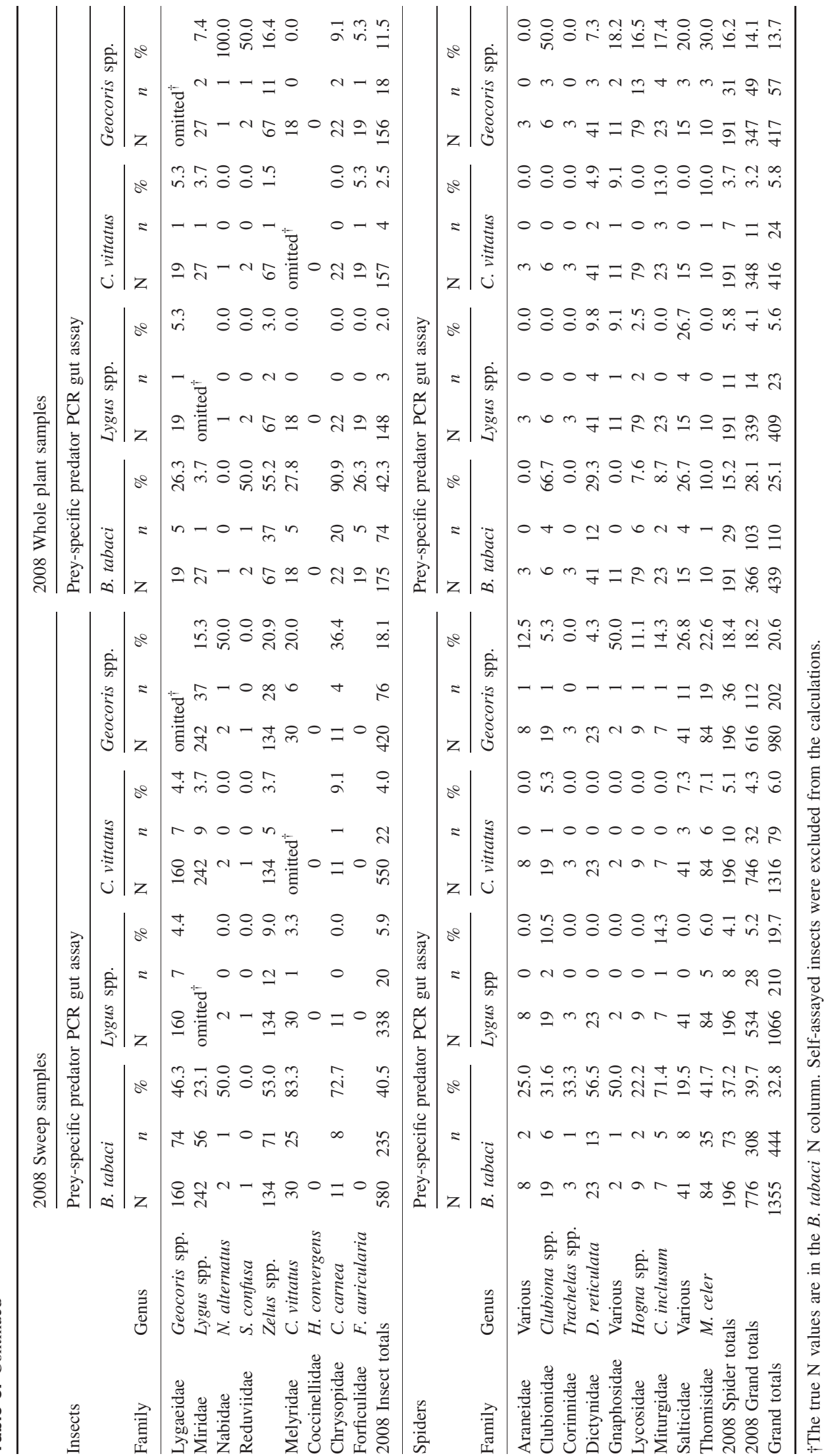

Published 2013. This article is a U.S. Government work and is in the public domain in the USA., Ecological Entomology, 38, 258-271 


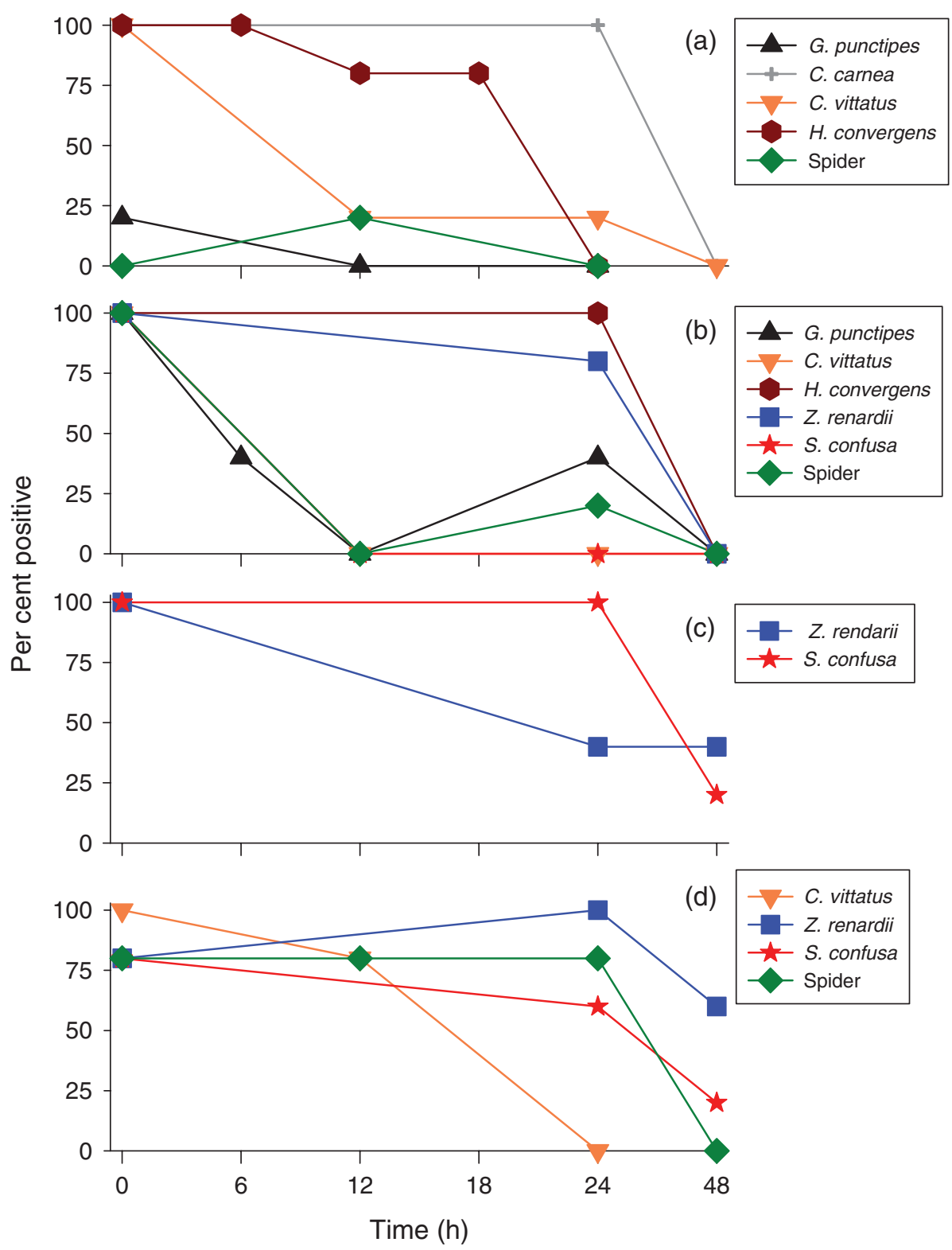

Fig. 1. Prey retention intervals for various predators after feeding on a single (a) Bemisia tabaci, (b) Lygus hesperus, (c) Collops vittatus, and (d) Geocoris punctipes ( $n=5$ predators for each time interval).

\section{Field study}

Arthropod populations. A total of 1794 predators, representing 17 arthropod families, were collected and analysed over the course of the 2-year study. The detailed results obtained for every predator taxon are given in Table 3. The most abundant predators encountered were Geocoris spp. $(n=397)$, Lygus spp. ( $n=319$, note that although Lygus spp. are economic pests that they are also predators), Z. renardii $(n=297)$, M. celer $(n=214)$, and Dictyna reticulata Gertsch and Ivie $(n=108)$. The average number of individuals collected by the sweep net (10 sweeps per sample) and whole plant sampling schemes are given in Fig. 2. Generally, $<0.5$ individuals of any given taxon were captured, regardless of the sampling scheme used. The sweep net sampling scheme yielded over three times more predators $(n=1,355)$ than the whole plant scheme $(n=439)$ (Table 3$)$. However, those predators with predominately ground-dwelling habits (e.g. earwig and many spider taxa) were more likely to be collected in whole plant samples.

Almost twice as many arthropods were collected in 2008 $(n=1142)$ than in $2007(n=652)$. This is most likely due to the later sampling dates (about 3 weeks later) used in 2008. Of the targeted prey species, C. vittatus, Lygus spp., and B. tabaci populations were approximately 3,5 , and 10 times greater in 2008, respectively, whereas the Geocoris spp. population

Published 2013. This article is a U.S. Government work and is in the public domain in the USA., Ecological Entomology, 38, 258-271 
(a) Sweep net samples

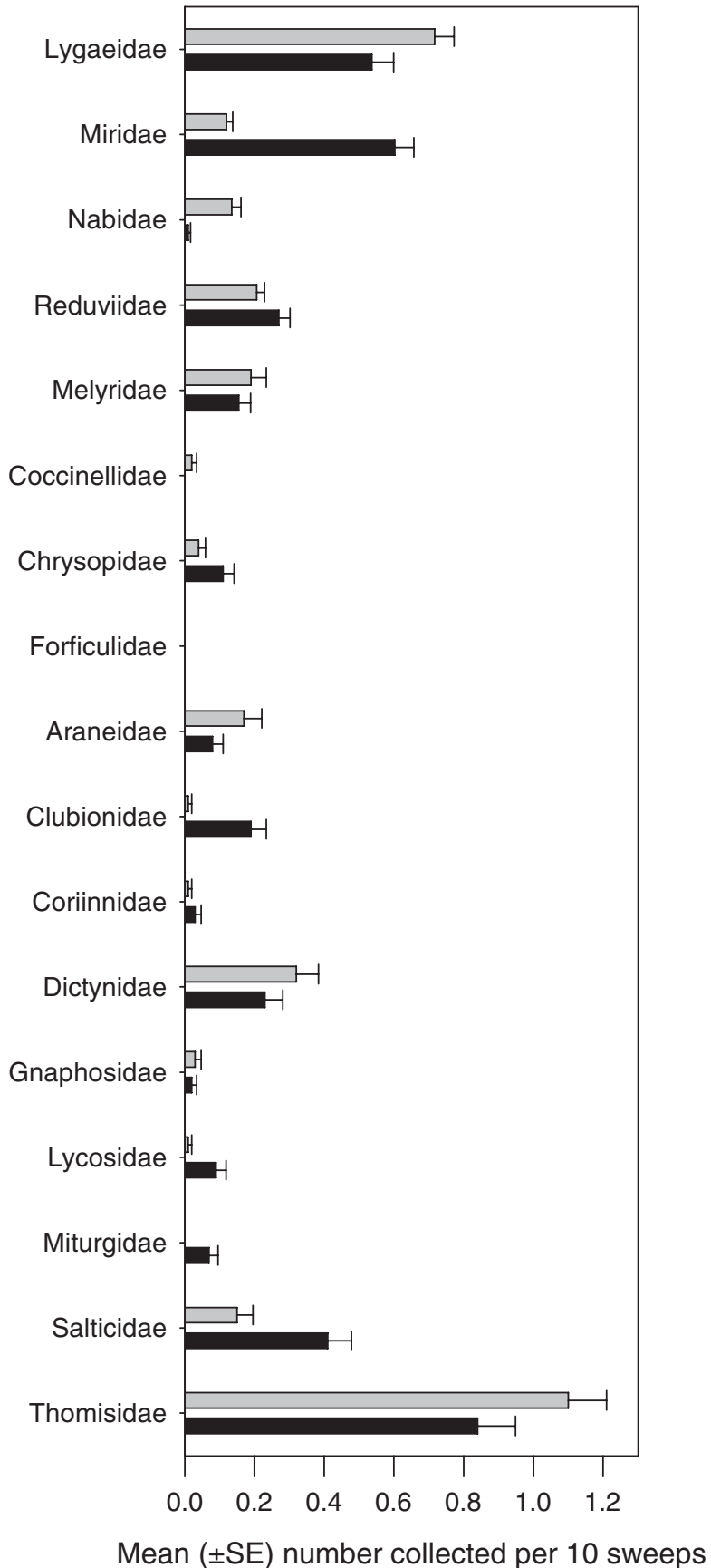

(b) Whole plant samples

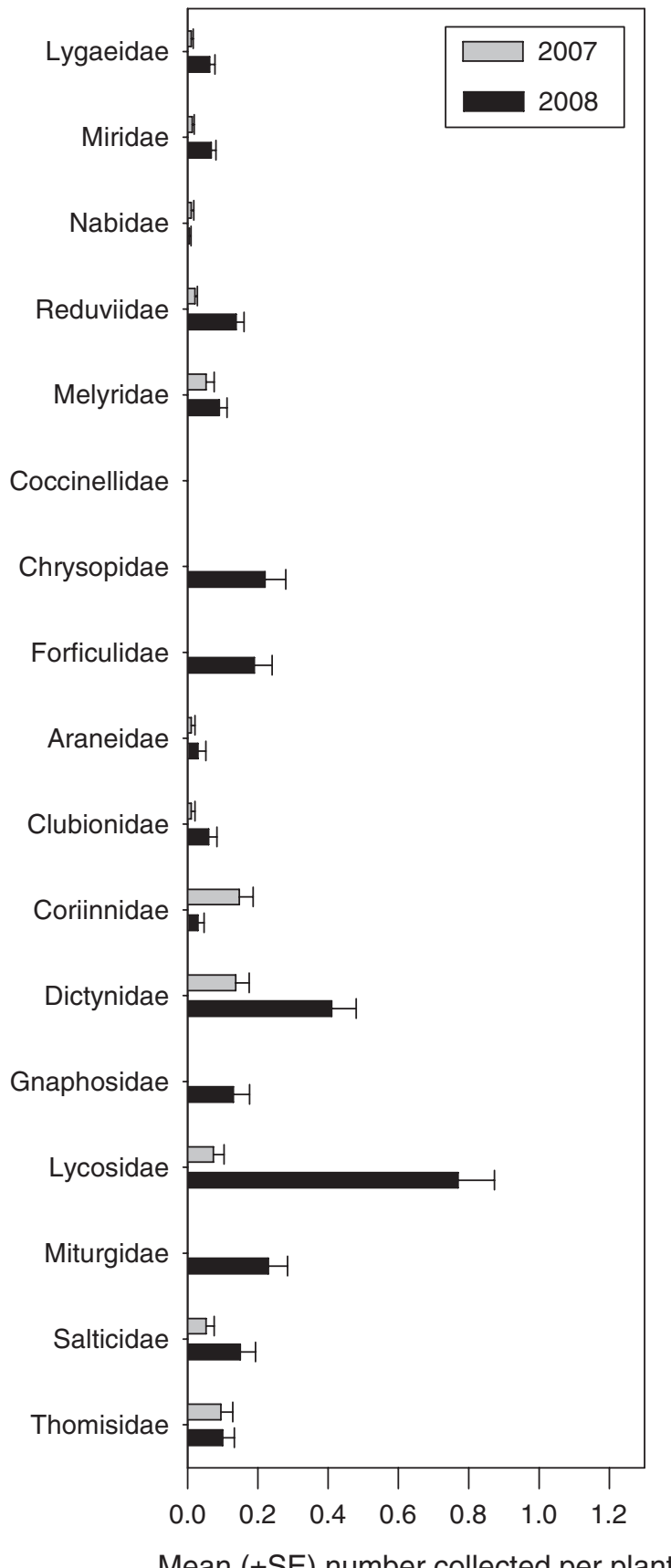

Fig. 2. The mean $( \pm$ SEM) densities of arthropod predators collected in 2007 (grey bars) and 2008 (black bars) in (a) sweep net samples $(n=100$ samples, each consisting of 10 sweeps) and (b) whole plant samples $(n=100)$. The sweep net samples were taken on 6 August 2007 and 8 September 2008, respectively. The whole plant samples were taken on 8 August 2007 and 4 September 2008, respectively.

was about the same each year (Table 3 and Fig. 3). In 2007, insect predators $(n=430)$ were encountered almost twice as often as spiders $(n=222)$ (Table 3). The Geocoris spp. complex $(n=218)$, consisting of $G$. pallens and $G$. punctipes, and $Z$. renardii $(n=96)$ were the dominant insect predator taxa; whereas Thomisidae ( $n=120$, primarily M. celer) was the dominant spider. Again, insect predators $(n=755)$ were encountered almost twice as often as spiders $(n=387)$ in 2008 (Table 3). However, the insect 'predator' population was dominated by the omnivorous Lygus spp. pest complex $(n=269)$. The key beneficial insect predators encountered in 2008 included Z. renardii $(n=201)$ and Geocoris spp.

Published 2013. This article is a U.S. Government work and is in the public domain in the USA., Ecological Entomology, 38, 258-271 


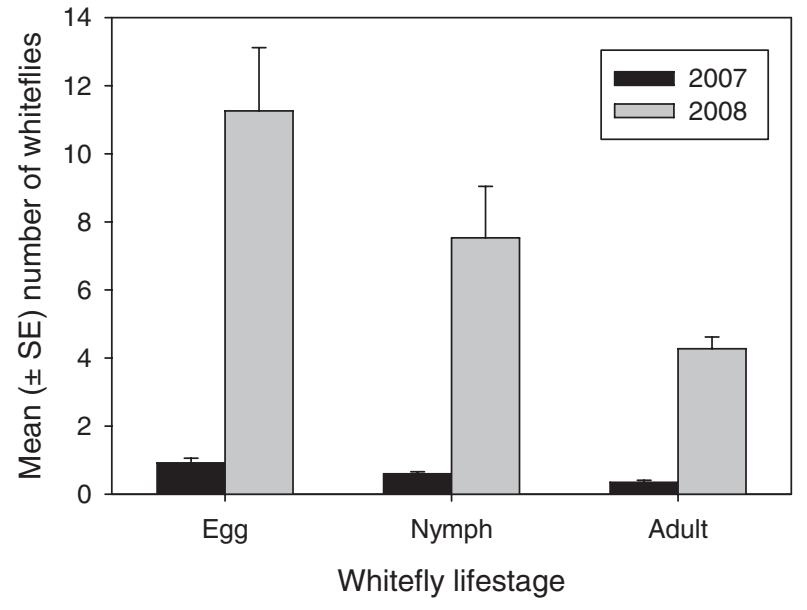

Fig. 3. The estimated abundance of Bemisia tabaci eggs and nymphs per 2.2-cm cotton leaf disc and adults per cotton leaf during 2007 and $2008(n=100)$.

$(n=179)$. The spider complex was dominated by Thomisidae $(n=94)$, Lycosidae $(n=88$, primarily Hogna spp.), and Dictynidae ( $n=64$, primarily $D$. reticulata) (Table 3 ).

PCR results. As expected, almost all of the self-assayed targeted prey, which served as positive assay controls, yielded positive PCRs (e.g. a field-collected Geocoris spp. yielded a positive PCR for Geocoris spp. DNA). That is, $99.5 \%$ $(n=397), 99.4 \%(n=319)$, and $96.8 \%(n=62)$ of the fieldcollected Geocoris spp., Lygus spp., and $C$. vittatus yielded a positive reaction to their respective PCRs. The frequencies of predation events detected by the four PCR assays for each predator taxon are given in Table 3. As expected, owing to its numerical dominance in the cotton fields (Fig. 3), the frequency of predation events recorded for most taxa was higher for B. tabaci than for the other targeted prey species (Table 3). Dominant (e.g. those with relatively high population densities) insect predator taxa yielding the highest frequencies of B. tabaci DNA in their gut included C. vittatus $(62.9 \%)$, Z. renardii (51.9\%), S. confusa (30\%), and Geocoris spp. $(28.2 \%)$. For spiders, Dictynidae $(30.6 \%)$ and Thomisidae (29\%) frequently contained B. tabaci DNA in their guts (Table 3). Predators with high frequencies of Lygus spp. DNA included Nabis alternatus Parshley (31.3\%), S. confusa (30.0\%), Geocoris spp. (21.2\%), Dictynidae (17.6\%), and Z. renardii (17.5\%). Collops vittatus DNA was not detected very frequently in predators. The most common taxa included Corinnidae (20\%), Miturgidae (10\%), and S. confusa (10\%). The predators most frequently containing Geocoris spp. DNA in their gut were Salticidae (28\%), S. confusa (25\%), N. alternatus (25\%), Z. renardii $(22.6 \%)$, and Thomisidae (22\%).

The overall results obtained from the gut analyses were pooled to identify trends in feeding activity on the prey types with respect to: (i) arthropod classes (insects vs spiders), (ii) sampling methods (sweep netting and whole plant counting), and (iii) seasons (2007 vs. 2008). The insect-predator complex yielded a significantly higher frequency of positive PCRs for
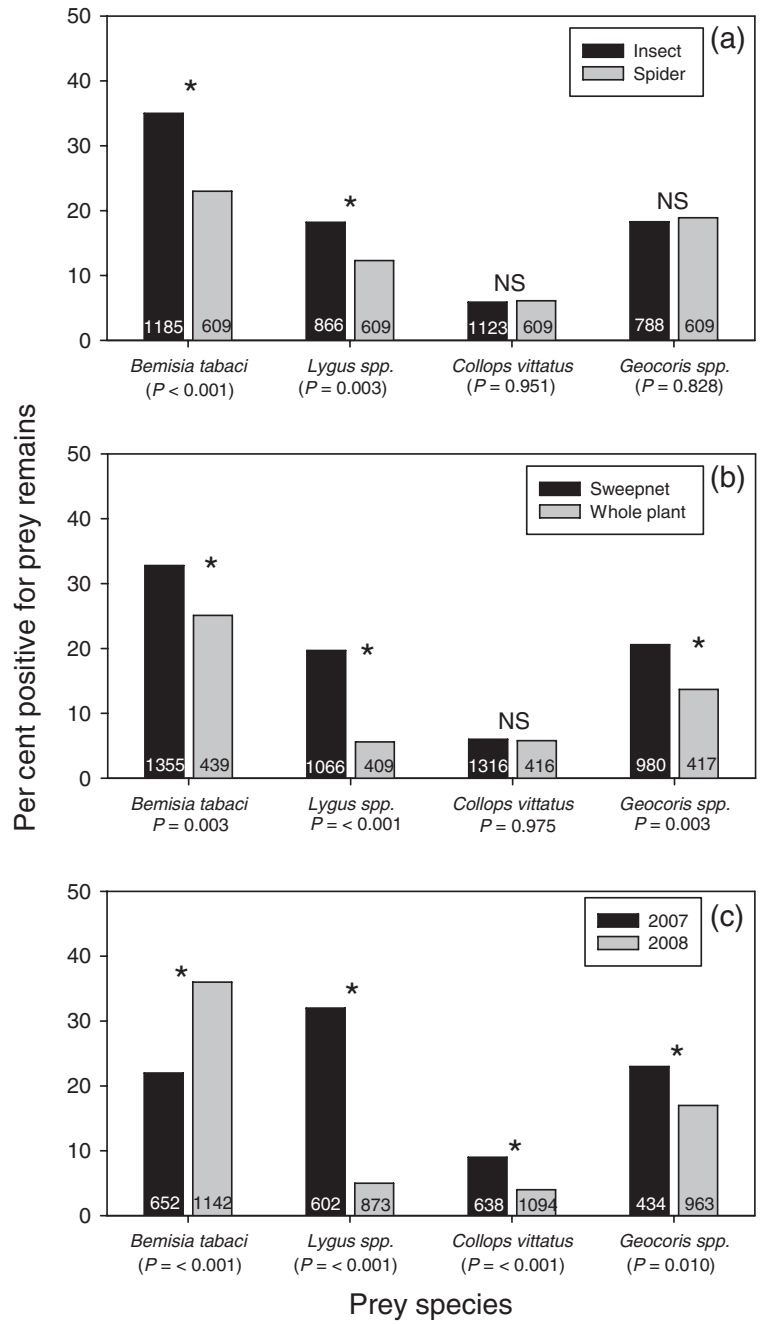

Fig. 4. A comparison of the frequency of: (a) predation events recorded for insect predators (black bars) and spiders (grey bars) on each prey species, (b) predation events recorded by the entire predator assemblage between the sweep net and whole plant sampling procedures, (c) predation events recorded by the entire predator assemblage between samples collected in 2007 and 2008. The numbers inside each bar is the sample size and the number in parenthesis below each prey type is the $z$-test statistic $P$-value.

the two major cotton pests, B. tabaci and Lygus spp. than the spiders (Fig. 4a). Overall, 34.9\% ( $n=414$ out of 1185) of the insects and $23.0 \%(n=140$ out of 609$)$ of the spiders contained B. tabaci DNA and $18.2 \%(n=158$ out of 866$)$ and $12.3 \%$ ( $n=75$ out of 609 ) contained Lygus spp. DNA, respectively. Collops vittatus DNA was detected at equally low frequencies between insects and spiders with about $6.0 \%$ of each population yielding a positive PCR. The frequency of Geocoris spp. DNA detected in the guts of the insect and spider population was also non-significant with about $18.0 \%$ of each population yielding a positive PCR.

A total of 1355 and 439 predators were collected over the course of the study using the sweep net and whole plant sampling schemes, respectively (Table 3). Data indicate that 
there was a significantly higher frequency of positive responses for B. tabaci, Lygus spp., and Geocoris spp. yielded by predators collected in sweep nets (Fig. 4b).

Differences in the frequency of predation events recorded by the predator assemblage between 2007 and 2008 are given in Fig. 4c. As expected, because of its much higher population in 2008, the percentage of predators containing B. tabaci DNA was significantly higher in 2008 than in 2007. However, the frequencies of predation events recorded for the other targeted prey were significantly higher in 2007 than in 2008.

\section{Discussion}

There is a need to obtain a better understanding of the impact that generalist predators have on the overall population dynamics of arthropods at the various trophic levels in order to identify the most promising candidates for biological pest control (Hagler, 2006; Harwood et al., 2007; Gagnon et al., 2011). The vast majority of predation studies conducted to date have focused only on identifying predators of a single herbivore pest (inter-guild predation). However, most arthropod predators are opportunistic feeders and do not discriminate between feeding guilds. Hence, more thorough studies are needed to identify the predator's propensity to engage in inter-guild (effective biological control) and intraguild (ineffective or interference biological control) predation events. For example, Rosenheim et al. (1993) evaluated the degree of inter- and intra-guild predation occurring in a relatively simple cotton arthropod assemblage containing aphids [Aphis gossypii (Glover)] and lacewings (C. carnea) together or aphids and lacewings plus Z. renardii, G. punctipes, and Nabis spp. It was determined that $C$. carnea alone was effective at suppressing aphid populations. However, lacewing populations decreased and aphid populations increased when higher order generalist predators were selectively added to the arthropod population. They concluded that the higher order predators preferred lacewings, thus hindering effective biological control of aphids by lacewings. Rosenheim et al. (1993) duly noted, however, that the inclusion/exclusion cage methodology they used only provided a crude estimate of the degree of intra-guild predation occurring. This was because: (i) field cage studies cannot precisely and simultaneously delineate which members of the predator complex were engaging in the predation events and (ii) the experimental protocol employed required manipulation of the insect population. The multigut analyses approach employed in this study complements the research conducted previously using other methods (e.g. field cage methodology) of predator assessment by pinpointing which predators are feeding on specific prey types under openfield and unmanipulated conditions.

The main goal of this study was to simultaneously probe the guts of field-collected predators for the presence of four prey items that occupy different levels of the arthropod food chain. The four prey types included a herbivore/pest, omnivore/pest, omnivore/beneficial, and carnivore/beneficial. To achieve this goal we: (i) developed a suite of insectspecific PCR assays, (ii) thoroughly screened each assay to achieve the desired specificity (e.g. genus or species specific), (iii) conducted predator feeding tests on each targeted prey to determine how long the target DNA could be detected after feeding, and (iv) simultaneously examined the gut contents of 1794 field-collected predators for the presence of the four targeted prey items. As duly noted in the literature, the development and screening of the PCR assays was rapid and relatively inexpensive (Greenstone, 2006; Greenstone et al., 2007; Monzó et al., 2010). The Lygus spp. and Geocoris spp. assays were genus specific. While in all likelihood we could have developed species-specific assays, we preferred having a broader range of detection for these two dominant genera. The $C$. vittatus and B. tabaci assays were both monospecific as they did not react with any of the other arthropod species tested.

One major complication resulted from the predator feeding tests under laboratory conditions. Specifically, many of the predators were reticent to feed on certain prey. The direct observations of feeding activity in the no-prey choice feeding arenas revealed some useful information that could be applied to the data yielded from the field study. For instance, most predators were disinclined to feed on G. punctipes and $C$. vittatus and $Z$. renardii and $S$. confusa flat out rejected adult $B$. tabaci (see below for more discussion). Also, an enormous amount of time, labour, and resources (e.g. PCR reagents) was devoted in the attempt to standardise the PCR gut assays. Specifically, many combinations of PCR parameters (e.g. number of cycles, annealing temperatures, PCR cocktails, etc.) were tested on the predators. Our goal was to standardise the assays so that they had relatively similar prey detection intervals for the various predators (note that only the PCR parameters that yielded the best results are presented here). In most cases a single prey item could be detected in predators immediately after feeding (but see the data yielded by $G$. punctipes and spiders after feeding on a single B. tabaci). However, the frequencies of prey detection beyond the initial feeding bouts were highly variable for each predator and preyspecific assay combination. In general, the larger prey items were retained in the gut of predators longer than their smaller counterparts. In short, we were not able to achieve satisfactory standardisation of the assays. These data and that obtained from similar laboratory feeding studies (Hagler \& Naranjo, 1997; Hagler, 1998; Zaidi et al., 1999; Chen et al., 2000; Greenstone \& Shufran, 2003; Harper et al., 2005; Fournier et al., 2008; and many others), highlight the weakest link in the multiple prey-specific gut assay research approach. That is, the detection limits of prey-specific assays vary too much. As a consequence we caution that direct comparisons of the predator frequencies between the four assays will be biased in favour of the most sensitive assays (see reviews on the caveats of molecular gut assays by Hagler and Naranjo (1996), Naranjo and Hagler (1998) and Sheppard and Harwood (2005)).

Although the sensitivities between the assays were highly variable, they were still useful for studying certain aspects of predation. For instance, we pooled the gut assay data to compare frequencies of predation events between arthropod classes, sampling methods, and growing seasons. The demography data showed that $34 \%$ (note that the percentage is $41 \%$ if the Lygus 
spp. complex is disregarded as a 'predator', see Table 3) of the arthropod predator complex (609 out of the 1794 collected) consisted of a wide variety of spiders. The overall gut content assay results revealed that $35 \%, 18 \%, 6 \%$, and $18 \%$ of the predaceous insects and $23 \%, 12 \%, 6 \%$ and $19 \%$ of the spiders contained B. tabaci, Lygus spp., C. vittatus, and Geocoris spp. DNA in their guts, respectively. A recent study quantified predation events in field cages on fourth instar L. hesperus that were each tagged with a unique protein. That study showed that $29 \%$ of the cotton arthropod-predator complex consisted of spiders and that they accounted for $35 \%$ of the documented predation events (e.g. 26 of the 74 events) (Hagler, 2011). Both of these studies suggest that spiders are important predators in the cotton agroecosystem and that they deserve more thorough investigation in the future.

As stated above, the qualitative PCR results showed that high proportions of the predaceous insect $(35 \%)$ and spider (23\%) complex contained B. tabaci DNA. This is not surprising given that the cotton fields were infested with whiteflies. The proportion of positive $B$. tabaci reactions yielded by the insect predators was similar to the feeding frequencies yielded by a B. tabaci-specific ELISA (Hagler \& Naranjo, 1994a,b). The Geocoris species complex was the most populous predator taxon ( $22 \%$ of the predator population) and they had a high frequency of B. tabaci DNA in their guts (Table 3). The high proportion of Geocoris spp. and spiders containing B. tabaci DNA identifies a discrepancy between the laboratory and field gut assay results. Specifically, the laboratory study showed that the B. tabaci gut assay was not reliable at detecting a single whitefly. This suggests that the field-collected Geocoris spp. and spiders that yielded a positive PCR probably obtained enough DNA to be detected by the assay as a result of multiple feeding events. Another discrepancy detected between the laboratory and field studies was the high frequency $(\approx 50 \%)$ of predation events recorded for the assassin bugs, Z. renardii and $S$. confusa. As mentioned above, these predators rejected whiteflies (all lifestages) in the in vitro feeding studies. These contradictory results could be due to one of three factors. First, perhaps the laboratory conditions were not conducive to the assassin bugs feeding on whiteflies. However, this is unlikely because they readily fed on other prey types under the same laboratory conditions. Second, the positive PCR gut assays yielded by the in situ specimens are 'false positive' reactions due to secondary predation events (Hagler \& Naranjo, 1996; Sheppard et al., 2005; J.R. Hagler and F. Blackmer, in prep.). That is, a false-positive predation event was recorded for a higher order predator because it fed on a lower order predator that had undigested whitefly DNA in its gut. While this potential source of error is widely recognised in the literature, there have been only a few studies that have addressed the impact that it has on the interpretation of gut assay data. Specifically, Harwood et al. (2001) concluded that false-positive reactions due to secondary predation were rare in their food chain study (e.g. aphid DNA was rarely detected in a predatory beetle that had fed on a spider that had previously consumed an aphid). Clearly, this is an area of research that deserves further investigation. Third, and most likely, the assassin bugs yielded 'false-positive' reactions due to external whitefly contamination during the sweep net collection process. Specifically, assassin bugs have tiny hairs on their legs that serve to grasp prey. Unfortunately, these hairs are also well adapted to catching debris (e.g. small insects, plant parts, etc.) in a sweep net. It should be noted that the legs from such field-collected specimens were amputated prior to subjecting them to the PCR in an attempt to eliminate this potential source of error. The overall frequency of predation events recorded on the omnivorous beneficial, Geocoris spp. (18.5\%) was slightly higher than on the omnivorous pest, Lygus spp. (15.8\%). However, there was a much higher frequency of Lygus spp. predation events (e.g., $31 \%$ and $5 \%$ for 2007 and 2008, respectively) detected when the Lygus spp., B. tabaci, and natural enemy populations were much lower in 2007. These data identify an area for further study. Specifically, further studies are needed to verify that predators are more effective biological control agents of Lygus spp. when less potential alternative prey are available.

Low predation frequencies were detected on the carnivore, C. vittatus (e.g. $6 \%$ of the predator population). These gut assay results concur with our direct feeding observations in that predators were reluctant to ingest this prey in the no-choice feeding arenas. The low frequencies of intra-guild predation recorded on $C$. vittatus coupled with the frequent inter-guild predation events recorded for it on B. tabaci here $(63 \%$ of the C. vittatus population) and by Hagler and Naranjo (1994) suggest that it is an important biological control agent. In addition, Hagler (2011) quantified predation rates of the entire cotton predator assemblage on protein-tagged $L$. hesperus. In that study, $C$. vittatus was second only to G. punctipes in the number of predation events recorded. However, these results expose yet another caveat to the interpretation of gut assay data. Specifically, we recently observed that $C$. vittatus scavenges as often as it engages in active predation (James R. Hagler, pers. obs.). It has been shown that carrion prey can be easily detected by pest-specific ELISA and PCR assays (Sunderland, 1996; Calder et al., 2005; Foltan et al., 2005; Juen \& Traugott, 2005). As such, predators that engage in carrion feeding will yield a high frequency of false-positive gut assay reactions for true predation. Currently, studies are underway using a prey marking gut assay approach to identify active from carrion predation events.

Another objective of this study was to determine if the method of arthropod collection affected the gut assay results. Specifically, our aim was to identify differences in arthropod population dynamics and predator gut analysis data obtained between sweep netting, a relative sampling scheme, and whole plant counting, an absolute sampling scheme (Ellington et al., 1984; Spurgeon, 2009). The rationale for using both sampling schemes was fourfold. First, the whole plant sampling scheme provided an absolute count of the number of arthropods inhabiting an individual cotton plant. However, this method is time consuming and does not yield many predators for gut analysis. Hence, the sweep net sampling scheme was used to bolster our predator sample sizes for gut analysis. Overall, we collected over three times more predators in the sweep nets than from whole plants in a fraction of the amount of time. Second, while we recognised that the sweep net sampling 
scheme would yield more predators, we also recognised that it would not be as effective at collecting ground-dwelling predators or those that tend to inhabit the lower portion of the plant canopy (e.g. earwigs and wolf spiders). A total of 1185 insect predators and 609 spiders were collected over the course of the study. Of these, 83\% (987) of the insects and $60 \%$ (368) of the spiders were collected by sweeping. Third, the method of predator collection was purported as a source of error for molecular gut content analyses due to the possibility of cross contamination during the sampling process (King et al., 2008). Subsequently, two studies showed that there were no significant differences between the proportions of spiders screening positive for the target prey when collected by sweep net versus hand collection (Harwood, 2008) or by vacuum versus hand collection (Chapman et al., 2010). However, a more recent study showed that a beat cloth collection method produced significantly more false-positive PCRs than a hand collection method (Greenstone et al., 2011). Our data shows that there is a significantly higher frequency of positive gut assay reactions recorded for three of the four targeted prey species that we collected in sweep nets. This could be because the arthropods collected on the upper part of the canopy are engaging in more predation or the predators are feeding in the confines of the sweep net after collection. In short, the sampling scheme employed for any given study can result in gut assay errors in the form of false-positive gut assay reactions. Clearly more caution is needed when selecting a sampling protocol for gut analysis research. Given this, researchers might choose to sacrifice a small degree of assay error in favour of using a collection method that yields enough specimens for a meaningful field study. Finally, as mentioned above, while much more labour intensive, the whole plant sampling scheme provides an absolute measure of the arthropod density.

In conclusion, the multiple gut content analyses approach was useful for identifying relative patterns of feeding activity by the cotton predator on prey items that occupy different niches of the food chain. The primers for all the targeted prey DNA were easy to obtain and the prey-specific gut assays were relativity easy and inexpensive to develop. However, the standardisation of the four assays was unattainable. This lack of standardisation leads to biased estimates of predation in favour of the most sensitive assays. In short, prey-specific assays only provide a qualitative estimate of predation owing to a variety of uncontrollable factors [see reviews by Hagler and Naranjo (1996) and Sheppard and Harwood (2005)]. Other major pitfalls with the multiple PCR gut assay approach that are not discussed very often in the literature are that PCR assays are not suited for mass screening because they are labour intensive and not suited for most research budgets because they are extremely costly (Fournier et al., 2008). This study also highlights that sampling methods can have an influence on gut assay data. The whole plant sampling scheme provided a more precise (e.g. absolute) estimate of the arthropod population on a per plant basis. However, it is much more labour intensive and does not yield many predator specimens. Conversely, sweep netting only provides a relative estimate of the arthropod population, it leads to biased estimates of predators that occupy the top half of the plant canopy, and it probably yielded higher frequencies of false-positive gut assay reactions. However, sweep netting is a very effective method for rapidly collecting enough specimens for a thorough field predation study. Ultimately, it is up to the investigator to select the sampling scheme that meets the research objectives.

\section{Acknowledgements}

We would like to thank Joel Gilley, Geoff Kimmel, Scott Machtley, Chris McNeely, Cassandra Price, Lori Stuart, Andrew Theis, and Alyssa Yamamura for their excellent technical support. The manuscript was improved by comments from Jesse de León and James Harwood. This work was funded, in part, by the USDA Risk Assessment and Mitigation Grant Program (RAMP \# ARZT-358320-G-30-505).

\section{References}

Agustí, N., de Vincente, M.C. \& Gabarra, R. (1999) Development of sequence amplified characterized region (SCAR) markers of Helicoverpa armigera: a new polymerase chain reactionbased technique for predator gut analysis. Molecular Ecology, 8, $1467-1474$.

Calder, C.R., Harwood, J.D. \& Symondson, W.O.C. (2005) Detection of scavenged material in the guts of predators using monoclonal antibodies: a significant source of error in measurement of predation? Bulletin of Entomological Research, 95, 57-62.

Chapman, E.G., Romero, S.A. \& Harwood, J.D. (2010) Maximizing collection and minimizing risk: does vacuum suction sampling increase the likelihood for misinterpretation of food web communities? Molecular Ecology Resources, 10, 1023-1033.

Chen, Y., Giles, K.L., Payton, M.E. \& Greenstone, M.H. (2000) Identifying key cereal aphid predators by molecular gut analysis. Molecular Ecology, 9, 1887-1898.

Debolt, J.W. (1982) Meridic diet for rearing successive generations of Lygus hesperus. Annals of the Entomological Society of America, 75, 119-122.

Ellington, J., Kiser, K., Ferguson, G. \& Cardenas, M. (1984) A comparison of sweepnet, absolute, and insectavac sampling methods in cotton ecosystems. Journal of Economic Entomology, 77, 599-605.

Foltan, P., Sheppard, S., Konvicka, M. \& Symondson, W.O.C. (2005) The significance of facultative scavenging in generalist predator nutrition: detecting decayed prey in the guts of predators using PCR. Molecular Ecology, 14, 4147-4158.

Fournier, V., Hagler, J., Daane, K., de León, J. \& Groves, R. (2008) Identifying the predator complex of Homalodisca vitripennis (Hemiptera: Cicadellidae): a comparative study of the efficacy of an ELISA and PCR gut content assay. Oecologia, 157, 629-640.

Gagnon, A., Doyon, J., Heimpel, G.E. \& Brodeur, J. (2011a) Prey DNA detection success following digestion by intraguild predators: influence of prey and predator species. Molecular Ecology Resources, 11, 1022-1032.

Gagnon, A., Heimpel, G.E. \& Brodeur, J. (2011b) The ubiquity of intraguild predation among predatory arthropods. PLOS ONE, 6, e28061.

Gariepy, T.D., Kuhlmann, U., Gilliott, C. \& Erlandson, M. (2007) Parasitoids, predators and PCR: the use of diagnostic molecular markers in biological control of arthropods. Journal of Applied Entomology, 13, 225-240. 
Glantz, S.A. (1997) Primer of Biostatistics. McGraw-Hill, New York, New York.

Greenstone, M.H. (2006) Molecular methods for assessing insect parasitism. Bulletin of Entomological Research, 96, 1-13.

Greenstone, M.H. \& Shufran, K.A. (2003) Spider predation: speciesspecific identification of gut contents by polymerase chain reaction. Journal of Arachnology, 31, 131-134.

Greenstone, M.H., Rowley, D.L., Weber, D.C., Payton, M.E. \& Hawthorne, D.J. (2007) Feeding mode and prey detectability halflives in molecular gut-content analysis: an example with two predators of the Colorado potato beetle. Bulletin of Entomological Research, 97, 201-209.

Greenstone, M.H., Weber, D.C., Coudron, T.C. \& Payton, M.E. (2011) Unnecessary roughness? Testing the hypothesis that predators destined for molecular gut-content analysis must be handcollected to avoid cross contamination. Molecular Ecology, 11, 286-293.

Hagler, J.R. (1998) Variation in the efficacy of several predator gut content immunoassays. Biological Control, 12, 25-32.

Hagler, J.R. (2006) Development of an immunological technique for identifying multiple predator-prey interactions in a complex arthropod assemblage. Annals of Applied Biology, 149, 153-165.

Hagler, J.R. (2011) An immunological approach to quantify consumption of protein-tagged Lygus hesperus by the entire cotton predator assemblage. Biological Control, 58, 337-345.

Hagler, J.R. \& Naranjo, S.E. (1994a) Determining the frequency of heteropteran predation on sweetpotato whitefly and pink bollworm using multiple ELISAs. Entomologia Experimentalis et Applicata, 72, 59-66.

Hagler, J.R. \& Naranjo, S.E. (1994b) Qualitative survey of two Coleopteran predators of Bemisia tabaci (Homoptera: Aleyrodidae) and Pectinophora gossypiella (Lepidoptera: Gelechiidae) using a multiple prey gut content ELISA. Environmental Entomology, 23, 193-197.

Hagler, J.R. \& Naranjo, S.E. (1996) Using gut content immunoassays to evaluate predaceous biological control agents: a case study. The Ecology of Agricultural Pests (ed. by W. O. C. Symondson and J. E. Liddell), pp. 383-399. Chapman and Hall, New York, New York.

Hagler, J.R. \& Naranjo, S.E. (1997) Measuring the sensitivity of an indirect predator gut content ELISA: Detectability of prey remains in relation to predator species, temperature, time, and meal size. Biological Control, 9, 112-119.

Harper, G.L., King, R.A., Dodd, C., Harwood, J.D., Glen, D.M., Bruford, MW. etal. (2005) Rapid screening of invertebrate predators for multiple prey DNA targets. Molecular Ecology, 14, 819-827.

Harwood, J.D. (2008) Are sweep net sampling and pitfall trapping compatible with molecular analysis of predation? Environmental Entomology, 37, 990-995.

Harwood, J.D., Phillips, S.W., Sunderland, K.D. \& Symondson, W.O.C. (2001) Secondary predation: quantification of food chain errors in an aphid-spider-carabid system using monoclonal antibodies. Molecular Ecology, 10, 2049-2057.

Harwood, J.D., Bostrom, M.R., Hladilek, E.E., Wise, D.H. \& Obrycki, J.J. (2007) An order-specific monoclonal antibody to Diptera reveals the impact of alternative prey on spider feeding behavior in a complex food web. Biological Control, 41, 397-407.

Juen, A. \& Traugott, M. (2005) Detecting predation and scavenging by DNA gut-content analysis: a case study using soil insect predator-prey system. Oecologia, 142, 344-352.
King, R.A., Read, D.S., Traugott, M. \& Symondson, W.O.C. (2008) Molecular analysis of predation: a review of best practice for DNAbased approaches. Molecular Ecology, 17, 947-963.

de León, J.H., Fournier, V., Hagler, J.R. \& Daane, K.M. (2006) Development of molecular diagnostic markers for the glassy-winged sharpshooter Homalodisca coagulata (Homoptera: Cicadellidae) for use in predator gut content examinations. Entomologia Experimentalis et Applicata, 119, 109-119.

Luck, R.B., Shepard, B. \& Kenmore, P. (1988) Experimental methods for evaluating arthropod natural enemies. Annual Review of Entomology, 33, 367-392.

Monzó, C., Sabater-Muñoz, B., Urbaneja, A. \& Castañera, P. (2010) Tracking medfly predation by the wold spider, Pardosa cribata Simon, in citrus orchards using PCR-based gut-content analysis. Bulletin of Entomological Research, 100, 145-152.

Naranjo, S.E. \& Ellsworth, P.C. (2009) Fifty years of the integrated control concept: moving the model and implementation forward in Arizona. Pest Management Science, 65, 1267-1286.

Naranjo, S.E. \& Flint, H.M. (1994) Spatial distribution of preimaginal Bemisia tabaci (Homoptera: Aleyrodidae) in cotton and development of fixed-precision sequential sampling plans. Environmental Entomology, 23, 254-266.

Naranjo, S.E. \& Flint, H.M. (1995) Spatial distribution of adult Bemisia tabaci (Homoptera: Aleyrodidae) in cotton and development and validation of fixed-precision sampling plans for estimating population density. Environmental Entomology, 24, 261-270.

Naranjo, S.E. \& Gibson, R.L. (1996) Phytophagy in Predaceous Heteroptera: effects on life history and population dynamics. Zoophytophagous Heteroptera: Implications for Life History and Integrated Pest Management (ed. by O. Alomar and R. N. Wiedenmann), pp. 57-93. Thomas Say Miscellaneous Publications, Entomological Society of America, Lanham, Maryland.

Naranjo, S.E. \& Hagler, J.R. (1998) Characterizing and estimating the effect of heteropteran predation. Predatory Heteroptera: Their Ecology and Use in Biological Control (ed. by M. Coll and J. R. Ruberson), pp. 171-197. Thomas Say Miscellaneous Publications, Entomological Society of America, Lanham, Maryland.

Rosenheim, J.A., Wilhoit, L.R. \& Armer, C.A. (1993) Influence of intraguild predation among generalist insect predators on the suppression of a herbivore population. Oecologia, 96, 439-449.

Sheppard, S.K. \& Harwood, J.D. (2005) Advances in molecular ecology: tracking trophic links through complex predator-prey food webs. Functional Ecology, 19, 751-762.

Sheppard, S.K., Bell, J., Sunderland, K.D., Fenlon, J., Skervin, D. \& Symondson, W.O.C. (2005) Detection of secondary predation by PCR analyses of the gut contents of invertebrate generalist predators. Molecular Ecology, 14, 4461-4468.

Spurgeon, D.W. (2009) Using marked Lygus hesperus (Knight) (Hemiptera: Miridae) adults to evaluate sweep net sampling in cotton. The Journal of Cotton Science, 13, 196-205.

Sunderland, K.D. (1996) Progress in quantifying predation using antibody techniques. The Ecology of Agricultural Pests: Biochemical Approaches(eds WOCSymondson, JELiddell)., pp 419-455. Chapman \& Hall, London, U.K.

Zaidi, R.H., Jaal, Z., Hawkes, N.J., Hemingway, J. \& Symondson, W.O.C. (1999) Can multiple-copy sequences of prey DNA be detected amongst the gut contents of invertebrate predators? Molecular Ecology, 8, 2081-2087.

Accepted 2 January 2013

First published online 26 March 2013 